\title{
UPAYA PENINGKATAN APRESIASI PUISI MELALUI PENDEKATAN KONTEKSTUAL DAN UNJUK KARYA SISWA DALAM PEMBELAJARAN BAHASA INDONESIA
}

\author{
Tri Andayani \\ Guru SMP Negeri 2 Mojosongo \\ Email: triandayani676@yahoo.com
}

\begin{abstract}
Abstrak. Penelitian ini bertujuan utuk (1) meningkatkan apresiasi puisi, (2) meningkatkan kemampuan menulis kreatif puisi, (3) meningkatkan kemampuan membaca puisi, (4) meningkatkan kemampuan menanggapi cara pembacaan puisi, dan (5) meningkatkan keaktifan dan motivasi belajar siswa SMP Negeri 2 Mojosongo. Penelitian Tindakan Kelas (PTK) ini dilakukan di SMP Negeri 2 Mojosongo. Subjek penelitian adalah semua siswa kelas VII B yang berjumlah 32 siswa. Pada penelitian ini terdapat tiga variabel yaitu variabel terikat (Y1) berupa apresiasi puisi, variabel tindakan yang pertama (X1) berupa pendekatan kontekstual, dan variabel tindakan yang kedua (X2) adalah unjuk karya. Metode yang digunakan dalam penelitian yaitu Penelitian Tindakan Kelas (PTK). Hasil penelitian dinyatakan bahwa penggunaan pendekatan kontekstual dan unjuk karya dapat meningkatkan apresiasi puisi. Rerata nilai kemampuan apresiasi puisi untuk menulis puisi meningkat semula rerata 69 menjadi 78,74 . Ketuntasan klasikal semula 3,1\% meningkat menjadi 96,87\%. Kemampuan apresiasi puisi untuk membaca puisi meningkat semula rerata 69,43 menjadi 78,53 . Ketuntasan klasikal semula $31,25 \%$ meningkat menjadi $100 \%$. Pemerolehan nilai hasil menanggapi cara pembacaan puisi juga mengalami peningkatan yaitu siklus I rerata 80,30 menjadi 81,87 saat siklus II. Ketuntasan klasikal mengalami peningkatan. Proses pembelajaran berupa keaktifan dan motivasi belajar siswa jug mengalami peningkatan.
\end{abstract}

Kata Kunci : Apresiasi Puisi, Pendekatan Kontekstual, Unjuk Karya Siswa

\begin{abstract}
This research aims to (1) increase the appreciation of poetry, (2) improve the ability to write creative poetry, (3) improve the ability of reading poetry, (4) improve the ability to respond to the ways poetry readings, and (5) enhance the liveliness and student's motivation at Junior High School. Classroom Action Research (CAR) was done in junior high Country 2 Mojosongo. The subjects were all students of class VII B totaling 32 students. In this study, there are three variables: the dependent variable (Y1) in the form of poetry appreciation, the first action variable (X1) in the form of a contextual approach, and the second action variable (X2) is a demonstration of the work. The method used in this research is the Classroom Action Research (CAR). The results of the study are using contextual approach and student performance of the works can enhance the appreciation of poetry. The mean value of the ability to write poetry's appreciation increased initially mean 69 to 78.74. Classical completeness initially rose $3.1 \%$ to $96.87 \%$. The ability to read a poem poetry appreciation originally mean increased 69.43 into 78.53 . $31.25 \%$ classical completeness initially increased to $100 \%$. Obtaining the value of the response to the way poetry reading also increased that the first cycle average of 80.30 into 81.87 is currently the second cycle. Classical completeness increased. The learning process in the form of activity and student's motivation are too increased.
\end{abstract}

Keywords: Poetry's Appreciation, Contextual Approach, Student's Performance of Works. 


\section{PENDAHULUAN}

Keterampilan berbahasa terdiri atas empat aspek yaitu menyimak, berbicara, membaca, dan menulis. Keempat keterampilan tersebut saling berkaitan satu dengan yang lain. Dalam pembelajaran di sekolah keterampilan berbahasa diajarkan secara terintegrasi. Dalam Kurikulum Tingkat Satuan Pendidikan (KTSP) terdapat silabus. Di dalam silabus disebutkan bahwa salah satu keterampilan berbahasa yang harus dikuasai oleh siswa SMP kelas VII adalah menulis puisi berkenaan dengan keindahan alam dan menulis puisi berkenaan dengan peristiwa yang pernah dialami siswa. Menulis puisi merupakan hal yang sangat penting bagi siswa karena sebagai sarana untuk mengungkapkan gagasan, rasa kagum, cita-cita, dan perasaan dalam bentuk bahasa yang singkat dan penuh makna dengan mempertimbangkan segi keindahan. Penulisan puisi dapat memberikan kenikmatan rasa, memperkaya kehidupan batin, menghaluskan budi, dan juga sering membangkitkan semangat hidup yang menyala bahkan mempertinggi keimanan.

Berdasarkan hasil pengamatan dan analisis dokumen hasil belajar siswa dalam hal menulis puisi ternyata karya siswa dalam bentuk puisi belum sesuai harapan. Dari 32 siswa kelas VII B SMP Negeri 2 Mojosongo Kabupaten Boyolali ternyata hanya satu siswa yang mendapatkan nilai tuntas. sedangkan 31 siswa memperoleh nilai di bawah kriteria ketuntasan belajar (KKM) yang ditentukan yaitu 75 . Hal ini berarti 96,90\% siswa belum tuntas untuk pencapaian kompetensi dasar menulis kreatif puisi berkenaan dengan keindahan alam. Pada umumnya para siswa mengalami kesulitan dalam hal pemilihan kata (diksi), menggunakan majas, menuangkan kalimat yang singkat tetapi padat makna ke dalam larik-larik puisi, dan dalam aspek persajakan (rima).

Berdasarkan hasil tanya jawab yang dilakukan guru dan siswa, kendala yang dialami para siswa tersebut disebabkan oleh beberapa faktor yaitu: (1) siswa kurang tertarik terhadap pembelajaran menulis puisi, (2) siswa mengalami kesulitan dalam menulis puisi bebas dari aspek pemilihan kata (diksi), persajakan (rima), dan penggunaan majas, (3) guru masih menggunakan pendekatan pembelajaran yang konvesional, dan (4) guru belum menyuruh siswa agar mengunjukkaryakan hasil karyanya sehingga siswa kurang termotivasi.

Berdasarkan data tersebut, maka perlu dilakukan perbaikan terhadap pembelajaran menulis puisi agar siswa dapat menuangkan gagasan, keinginan, rasa kagum atas ciptaan Tuhan, dan menghargai alam dalam bentuk puisi bebas berkenaan dengan keindahan alam. Selain itu, penulis perlu melakukan perbaikan terhadap pembelajaran menulis puisi berkenaan dengan peristiwa yang pernah dialami siswa dengan memperhatikan aspek-aspek keindahan puisi. Guru perlu menggunakan pendekatan tertentu dan menyuruh siswa agar melakukan unjuk karya (membaca) hasil karyanya sehingga mampu mengatasi permasalahan-permasalahan tersebut. Pendekatan yang dipandang mampu mengatasi permasalahan rendahnya kemampuan menulis kreatif puisi berkenaan dengan keindahan alam 
dan berkenaan dengan peristiwa yang pernah dialami siswa adalah pendekatan kontekstual yaitu pembelajaran di alam sekitar sekolah misalnya di taman sekolah. Dengan penggunaan pendekatan ini diharapkan siswa lebih tertarik dan serius dalam pembelajaran sehingga dapat meningkatkan kemampuannya dalam menulis puisi berkenaan dengan keindahan alam.

Menurut Suminto A. Sayuti (2002: 365) apresiasi merupakan hasil usaha membaca dalam mencari dan menemukan nilai hakiki puisi lewat pemahaman dan penafsiran sistematik yang dapat dinyatakan dalam bentuk tertulis. Melalui kegiatan apresiasi tersebut diharapkan timbul kegairahan dalam diri pembaca untuk lebih memasuki dunia puisi, berbagai dunia yang juga menyediakan alternatif pilihan untuk menghadapi permasalahan kehidupan yang sebenarnya. Sementara itu, S. Parman Natawijaya (1982:1) mengungkapkan bahwa apresiasi adalah penghargaan dan pemahaman atas sesuatu hasil seni atau budaya. Lebih lanjut S. Parman Natawijaya menjelaskan bahwa sesuatu itu baik dan mengerti itu baik. Dengan demikian kegiatan apresiasi terhadap sesuatu itu membentuk suatu pengalaman baru yang berkenaan dengan hal atau suatu peristiwa dalam kehidupan sehari-hari, misalnya menulis kemudian membacakan puisi. Perkataan apresiasi menurut S. Effendi adalah kegiatan. Ia mendefinisikan apresiasi sastra adalah kegiatan menggauli cipta sastra dengan sungguh-sungguh hingga tumbuh pengertian, penghargaan, kepekaan pikiran kritis dan kepekaan perasaan yang baik terhadap cipta sastra (1982: 7). Berdasar definisi tersebut tersirat dua kegiatan yaitu kegiatan dokumentatif dan kegiatan kreatif (produktif). Empat tingkatan apresiasi menurut Wardani (1981: 20) adalah tingkat menggemari, tingkat menikmati, tingkat mereaksi, dan tingkat produktif.

Berdasarkan uraian di atas, dapatlah dikatakan bahwa hakikat apresiasi adalah kegiatan menggauli baik secara dokumentatif dan kreatif (produktif) yang dilakukan dengan sungguh-sungguh hingga tumbuh pengertian, penghargaan, kepekaan pikiran kritis, dan kepekaan perasaan yang baik terhadap suatu karya. Herman J. Waluyo ( 2002: 1) mengatakan bahwa puisi adalah karya sastra dengan bahasa yang dipadatkan, dipersingkat, dan diberi irama dengan bunyi yang padu dan pemilihan kata-kata kias. Coleridge dalam Pradopo (2002: 7) mengemukakan bahwa puisi adalah kata-kata yang indah dalam susunan terindah, penyair memilih kata-kata yang setepatnya dan disusun secara sebaik-baiknya misalnya seimbang, simetris antara satu unsur dengan unsur yang lain sangat erat hubungannya. Menurut Kinayati Djojosuroto (2009: 9) puisi adalah suatu sistem penulisan yang margin kanan dan penggantian barisnya ditentukan secara internal dalam sutu mekanisme yang terdapat dalam baris itu sendiri. Putu Arya Tirtawirya (1982: 9) menjelaskan bahwa puisi adalah pengungkapan secara implisit, samar dengan makna yang tersirat, di mana kata-kata condong pada artinya yang konotatif. Hal tersebut sesuai pernyataan Rachmat Joko Pradopo (2009: 1) puisi sebagai salah satu sebuah karya seni sastra dapat dikaji dari bermacam-macam aspek. Puisi dapat dikaji 
struktur dan unsur-unsurnya, mengingat bahwa puisi adalah struktur yang tersusun dari bermacam-macam unsur dan sarana-sarana kepuitisan. Berdasarkan beberapa definisi di atas dapat disimpulkan bahwa puisi adalah ungkapan perasaan, emosi, ide yang disampaikan dengan bahasa yang indah susunannya dan mempunyai makna yang luas. Puisi dibangun dua unsur pokok yaitu struktur fisik dan struktur batin. Struktur batin puisi terdiri atas tema, nada, perasaan, dan amanat. Struktur fisik puisi yaitu diksi, pengimajian, kata konkret, majas, versifikasi, dan tipografi puisi. Herman $J$. Waluyo (2003: 44) menjelaskan bahwa apresiasi biasanya dikaitkan dngan kegiatan seni. Puisi adalah cabang dari seni sastra. Appresiasi puisi berkaitan dengan kegiatan yang ada sangkut pautnya dengan puisi yaitu mendengar atau membaca puisi dengan penghayatan yang sungguh-sungguh, menulis puisi, mendeklamasikannya, dan menulis resensi puisi.

Suatu proses pembelajaran dikatakan menggunakan pendekatan kontekstual (CTL) bila guru pada pembelajaran telah mengaitkan materi dengan kehidupan nyata siswa sehingga guru mampu mendorong siswa membuat hubungan antara pengetahuan yang dimiliki dengan penerapannya dalam kehidupan sehari-hari. Pembelajaran kontekstual memenuhi tujuh komponen. Tujuh komponen tersebut adalah kontruktivisme, Inquiry, questioning, learning community, modeling. reflection, dan authentic assessment. Unjuk Karya merupakan penampilan di depan guru dan siswa (temanteman) untuk membacakan hasil karyanya. Jika dalam hal penulisan puisi maka membacakan puisi hendaknya dengan pelafalan, volume, intonasi, dan kemampuan pembaca untuk menarik perhatian. Dengan pembacaan puisi yang tepat maka guru dan siswa dapat ikut merasakan ungkapan hati penulis puisi.

Berbagai penelitian tentang apresiasi puisi pernah dilakukan para peneliti terdahulu. Sutrimah (2009) dari hasil penelitiannya menyimpulkan penerapan pembelajaran dengan menggunakan media lagu dalam menulis puisi bebas mampu meningkatkan keaktifan dalam menulis puisi bebas. Penelitian tentang apresiasi puisi juga dilakukan oleh Suyitno (2004) dengan bebrapa simpulan; 1) Siswa di SMU Negeri 1 Surakarta memiliki modal dasar pembelajaran yang cukup bagus; b) tujuan apresiasi puisi di SMU Negeri 1 Surakarta dikaitkan dengan aspek-aspek pengetahuan, pemahaman, dan penggunaan bahasa puisi pada khususnya dan bahasa keseharian pada umumnya; c) bahan pembelajaran apresiasi puisi pada SMU Negeri 1 Surakarta mengacu pada pembelajaran apresiasi langsung; d) metode ceramah, tanya jawab, dan diskusi digunakan oleh SMU Negeri 1 Surakarta dan SMU Negeri 8 Surakarta; e) media pembelajaran apresiasi puisi di SMU Negeri 1 dan SMU Negeri 8 Surakarta dapat menstimuli pengalaman buatan, pengalaman aktual, dan pengalaman sosialemosional intelektual siswa; f) penilaian mengutamakan kemampuan berapresiasi puisi anak didik selama pembelajaran dilakukan secara acak untuk memberi nilai lebih kepada peserta didik yang menonjol apresiasi puisinya; g) 
beberapa faktor penunjang lain pemelajaran apresiasi puisi tidak diperdayagunakan; dan h) siswa SMU Negeri 1 dan SMU Negeri 8 Surakarta berhasil dalam pembelajaran apresiasi puisi secara kognitif walaupun secara efektif dan psikomotorik belum berhasil. Persamaan dua penelitian tersebut dengan penelitian ini adalah menyoroti kegiatan pembelajaran apresiasi puisi. Sedangkan perbedaannya adalah subjek penelitian sebelumnya adalah siswa SMA sedangkan pada penelitian ini siswa SMP.

\section{METODE PENELITIAN}

Penelitian dilakukan di Sekolah Menengah Pertama (SMP) Negeri 2 Mojosongo Kabupaten Boyolali Provinsi Jawa Tengah. Pelaksanaan penelitian ini adalah semester dua tahun pelajaran 2015/2016. Penelitian berlangsung selama 5 bulan terdiri dari dua siklus. Setiap siklus terdiri dari empat kegiatan yaitu perencanaan, tindakan, pengamatan, dan refleksi. Subjek penelitian tindakan kelas ini adalah siswa kelas VII B SMP Negeri 2 Mojosongo Kabupaten Boyolali. Penulis memilih kelas tersebut sebagai sumber data penelitian karena materi pembelajaran berkaitan dengan apresiasi puisi sebagai materi kelas VII B semester dua. Selain hal tersebut, siswa-siswa kelas VII B kurang mampu mengapresiasi puisi dalam hal menulis puisi yaitu pemilihan kata (diksi), menggunakan majas, menuangkan kalimat yang singkat dan padat ke dalam lariklarik puisi, dan dalam aspek persajakan (rima). Hal tersebut menjadikan tingkat ketuntasan belajar sangat rendah. Sejumlah 96,90\% siswa tidak tuntas. Semangat belajar bahasa Indonesia saat proses pembelajaran sangat rendah. Siswa merasa jenuh bahkan cenderung mengantuk sebab penggunaan metode ceramah yang dilakukan oleh guru. Sebagian besar siswa belum mampu membaca puisi secara maksimal.

Teknik yang digunakan untuk mengumpulkan data apresiasi puisi adalah menggunakan bentuk teknik tes dan nontes. Teknik tes adalah tes tertulis dan unjuk karya oleh siswa. Tes tertulis digunakan untuk mengetes kemampuan menulis puisi. Tes unjuk karya digunakan untuk mengetes kemampuan membaca puisi. Sedangkan teknik nontes adalah pengamatan (observasi). Pengamatan (observasi) yang dilakukan guru dan observer berguna untuk memberikan penilaian terhadap kemampuan siswa menanggapi cara pembacaan puisi dan keaktifan serta motivasi belajar siswa.

Data yang diperoleh kemudian dianalisis secara deskriptif komparatif dilanjutkan refleksi. Analisis deskriptif komparatif dilakukan dengan cara membandingkan data tulisan puisi kondisi awal dengan siklus I, siklus I dengan siklus II, dan kondisi awal dengan kondisi akhir. Refleksi dilakukan untuk menarik simpulan berdasarkan deskriptif komparatif. Langkah berikutnya adalah memberikan ulasan berdasar ulasan tersebut untuk menentukan tindak lanjut berikutnya. Sebagai patokan untuk menilai keberhasilan atas perlakuan yang dipraktikkan, selanjutnya dirumuskan indikator kinerja seperti berikut. a) tingkat apresiasi puisi meningkat dari rendah menjadi tinggi, b) nilai menulis puisi meningkat dari rata-rata 69,16 menjadi 75 , c) nilai 
membaca puisi meningkat dari rata-rata 69,43 menjadi 75, d) ketuntasan apresiasi puisi secara klasikal meningkat dari 3,12\% menjadi $85 \%$. Sementara Indikator proses pembelajaran meliputi; siswa aktif sebesar $92 \%$, dan siswa termotivasi mengikuti pembelajaran sebesar $85 \%$.

\section{HASIL DAN PEMBAHASAN}

\section{Deskripsi Kondisi Awal}

Berdasarkan hasil dokumentasi penilaian secara tertulis hasil belajar siswa dalam menulis kreatif puisi ternyata nilai karya siswa dalam bentuk puisi belum sesuai harapan. Dari 32 siswa kelas VII B SMP Negeri 2 Mojosongo Boyolali ternyata hanya 1 siswa yang mendapatkan nilai sama dengan atau lebih dari 75 , sedangkan 31 siswa memperoleh nilai di bawah kriteria ketuntasan Minimal (KKM). Kriteria ketuntasan Minimal (KKM) yang ditentukan oleh Guru-Guru Bahasa Indonesia di SMP Negeri 2 Mojosongo adalah 75. Hal ini berarti $96,90 \%$ siswa belum tuntas berkenaan dengan kompetensi dasar menulis kreatif puisi berkenaan dengan keindahan alam. Pada umumnya para siswa mengalami kesulitan dalam hal pemilihan kata (diksi), menggunakan majas, menuangkan kalimat yang singkat dan padat ke dalam larik-larik puisi, dan dalam aspek persajakan (rima).

Siswa saat membacakan puisi (unjuk karya) hasil karyanya juga mengalami kesulitan. Siswa membacakan puisi (unjuk karya) dengan pelafalan, intonasi, ekspresi, dan kemampuan menarik perhatian pendengar masih rendah. Hasil dokumentasi penilaian terhadap unjuk karya siswa menunjukkan bahwa siswa yang membaca puisi dengan maksimal hanyalah 2 siswa atau $6,24 \%$. Sejumlah 30 siswa atau $93,76 \%$ siswa belum mampu membacakan puisi hasil tulisannya (karyanya) secara maksimal. Dua siswa memperoleh nilai sama dengan atau lebih dari 75 . Sedangkan 30 siswa mendapat nilai kurang dari 75. Adapun Kriteria Ketuntasan Minimal (KKM) yang ditentukan adalah 75. Siswa yang tidak unjuk karya dan guru mengamati unjuk karya pembaca puisi kemudian menanggapi cara pembacaan puisi tersebut.

\section{Hasil Perlakuan Siklus 1}

Hasil penilaian terhadap karya puisi berupa nilai tertinggi, nilai terendah, nilai rerata, dan rentang nilai tercantum di tabel 1 di bawah ini. Puisi yang ditulis siswa bertema Berkenaan dengan Keindahan Alam pada Siklus I dengan hasil seperti yang tertera di bawah ini. 
Tabel 1. Nilai Menulis Kreatif Puisi Berkenaan dengan keindahan Alam pada Siklus I

\begin{tabular}{clc}
\hline No. & \multicolumn{1}{c}{ Uraian } & $\begin{array}{c}\text { Nilai Ulangan } \\
\text { Harian }\end{array}$ \\
\hline 1 & Nilai terendah & 67 \\
2 & Nilai tertinggi & 80 \\
3 & Nilai Rerata & 75,30 \\
4 & Rentang Nilai & 13 \\
\hline
\end{tabular}

Berdasar tabel di atas diketahui bahwa nilai terendah berskor 67 . Nilai tertinggi 80 , dan nilai rerata yang dicapai oleh siswa kelas VII B adalah 75,30. Selain nilai menulis kreatif puisi, dapat diketahui tentang data nilai hasil pembacaan puisi yang dilakukan oleh siswa dengan unjuk karya saat siklus I. Tabel 2 di bawah merupakan nilai unjuk karya membaca puisi saat siklus I.

Tabel 2. Nilai Pembacaan Puisi Hasil Karya Siswa Pada Siklus I

\begin{tabular}{clc}
\hline No & \multicolumn{1}{c}{ Uraian } & $\begin{array}{c}\text { Nilai Ulangan } \\
\text { Harian }\end{array}$ \\
\hline 1 & Nilai terendah & 70 \\
2 & Nilai tertinggi & 85 \\
3 & Nilai Rerata & 75 \\
4 & Rentang Nilai & 15 \\
\hline
\end{tabular}

Berdasar tabel di atas diketahui bahwa nilai terendah berskor 70 . Nilai tertinggi 85 , dan nilai rerata yang dicapai oleh siswa kelas VII B adalah 75. Rentang nilai tertinggi dengan nilai terendah adalah 15 .

\section{Hasil Perlakuan Siklus 2}

Hasil penilaian terhadap karya puisi berupa nilai tertinggi, nilai terendah, nilai rerata, dan rentang nilai siklus II tercantum di tabel 3 di bawah ini.
Tabel 3. Nilai Menulis Kreatif Puisi Berkenaan dengan Peristiwa yang Pernah Dialami Siswa Pada Siklus II

\begin{tabular}{clr}
\hline No & \multicolumn{1}{c}{ Uraian } & $\begin{array}{c}\text { Nilai Ulangan } \\
\text { Harian }\end{array}$ \\
\hline 1 & Nilai terendah & 75 \\
2 & Nilai tertinggi & 87 \\
3 & Nilai Rerata & 78,74 \\
4 & Rentang Nilai & 12 \\
\hline
\end{tabular}

Berdasar tabel di atas diketahui bahwa nilai terendah berskor 75 . Nilai tertinggi 87 , dan nilai rerata yang dicapai oleh siswa kelas VII B adalah 78,74 . Rentang nilai tertinggi dan nilai terendah adalah 12. Selain nilai menulis kreatif puisi, dapat diketahui tentang data nilai hasil pembacaan puisi yang dilakukan oleh siswa dengan unjuk karya saat siklus II. Tabel di bawah ini merupakan nilai unjuk karya membaca puisi saat siklus II.

Tabel 4. Nilai Pembacaan Puisi Hasil Karya Siswa Pada Siklus II

\begin{tabular}{clc}
\hline No & \multicolumn{1}{c}{ Uraian } & $\begin{array}{c}\text { Nilai Ulangan } \\
\text { Harian }\end{array}$ \\
\hline 1 & Nilai terendah & 75 \\
2 & Nilai tertinggi & 88 \\
3 & Nilai Rerata & 78,53 \\
4 & Rentang Nilai & 13 \\
\hline
\end{tabular}

Berdasar tabel di atas diketahui bahwa nilai terendah berskor 75 . Nilai tertinggi 88 , dan nilai rerata yang dicapai oleh siswa kelas VII B adalah 78,53. Rentang nilai adalah 13.

\section{Pembahasan Antarsiklus}

Berdasarkan pembahasan siklus I dan II, terjadi peningkatan dari siklus I sampai siklus II. Tabel 5 di bawah ini adalah gambaran terjadi peningkatan apresiasi puisi yaitu menulis kreatif puisi, membaca puisi, dan menanggapi cara pembacaan puisi. 
Tabel 5. Ketuntasan Klasikal Nilai yang Dicapai Siswa

\begin{tabular}{|c|c|c|c|c|c|}
\hline \multirow[b]{2}{*}{ No } & \multirow[b]{2}{*}{ Kegiatan } & \multicolumn{2}{|l|}{ Rerata } & \multicolumn{2}{|c|}{ Ketuntasan Klasikal } \\
\hline & & Siklus I & Siklus II & Siklus I & Siklus II \\
\hline 1 & Menulis kreatif puisi & 75,30 & 78,74 & $66,6 \%$ & $96,8 \%$ \\
\hline 2 & Membaca Puisi & 75 & 78,53 & $50 \%$ & $100 \%$ \\
\hline 3 & $\begin{array}{l}\text { Menanggapi cara } \\
\text { pembacaan puisi }\end{array}$ & 80,3 & 81,87 & - & - \\
\hline
\end{tabular}

Berdasarkan tabel di atas dapat diketahui bahwa indikator variabel menulis kreatif puisi siklus I rerata mencapai 75,30, ketuntasan klasikal mencapai $66,6 \%$. Setelah dilakukan tindakan berikutnya yaitu siklus II, rerata meningkat menjadi 78,74 dan 96,8\% untuk ketuntasan klasikal. Indikator variabel membaca puisi siklus I rerata mencapai 75, ketuntasan klasikal adalah $50 \%$. Setelah dilakukan tindakan berikutnya yaitu siklus II, rerata meningkat menjadi 78,53 dan $100 \%$ untuk ketuntasan klasikal. Adapun rerata untuk nilai menanggapi cara pembacaan puisi adalah 80,3 untuk siklus I meningkat menjadi 81,87 saat akhir siklus II. Jadi mengalami peningkatan 1,57. Adapun peningkatan hasil menulis kreatif puisi mulai kondisi awal, siklus I, dan siklus II, serta target kinerja dapat diperhatikan pada gambar (grafik) 1 berikut ini.
Grafik 1. Rerata Menulis Kreatif Puisi

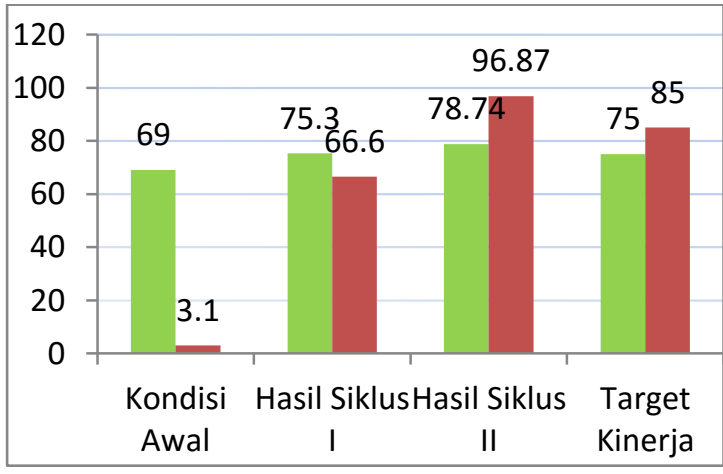

Rata-rata Nilai $\square$ Tuntas Belajar

Berdasarkan grafik di atas dapat diketahui bahwa rerata menulis kreatif puisi pada akhir siklus II mengalami peningkatan dibandingkan kondisi awal dan siklus I. Target kinerja berhasil dilampaui oleh kelas VII B. Adapun peningkatan hasil membaca puisi mulai kondisi awal, siklus I, siklus II, dan target kinerja dapat diperhatikan pada gambar (grafik) di bawah ini. 
Grafik 2. Rerata Hasil Pembacaan Puisi

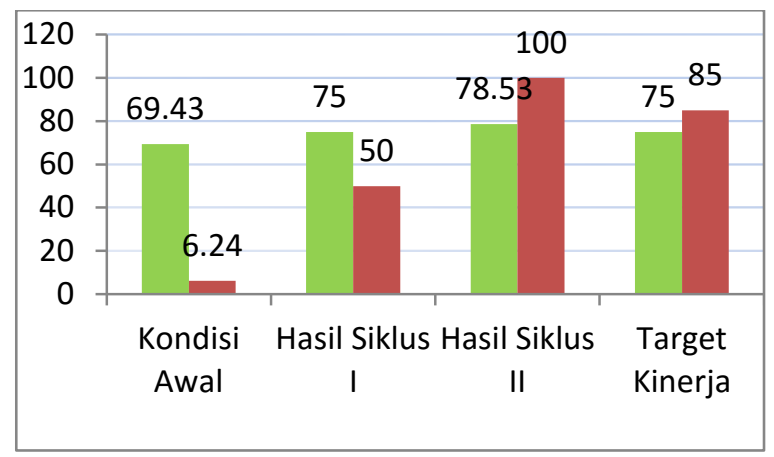

Rata-rata Nilai $\square$ Tuntas Belajar

Berdasarkan gambar di atas dapat diketahui bahwa rerata membaca puisi pada akhir siklus II mengalami peningkatan dibandingkan kondisi awal dan siklus I yaitu 78,74. Target kinerja yang ditentukan yaitu rerata 75 dan ketuntasan klasikal $85 \%$ berhasil dilampaui oleh siswa kelas VII B. Adapun target kinerja yang dicapai siswa saat akhir siklus II adalah 100\%. Untuk indikator keberhasilan proses pembelajaran yang terdiri dari keaktifan dan motivasi belajar siswa mengalami peningkatan juga. Saat kondisi awal, siswa yang aktif dan motivasi hanyalah $50 \%$ atau 16 siswa meningkat menjadi keaktifan $93 \%$ siswa atau 31 siswa dan motivasi $87,5 \%$ atau 30 siswa.

\section{PEMBAHASAN}

Memperhatikan deskripsi tiap-tiap siklus tindakan I dan II, serta realita yang terjadi selama proses tindakan berlangsung maka peningkatan apresiasi puisi meliputi menulis puisi, membacakan puisi yang ditulis, dan menanggapi cara pembacaan puisi melalui pendekatan kontekstual dan unjuk karya pada siswa kelas VII B SMP Negeri 2 Mojosongo dapat disebut berhasil secara maksimal. Upaya peneliti atau guru dalam meningkatkan pembelajaran yang bermakna sesuai dengan apa yang dikemukakan Yamin (2007:75) bahwa pembelajaran hendaknya lebih berpusat pada siswa, sehingga siswa ikut berpartisipasi dalam proses pembelajaran telah terwujud. Dengan pembelajaran berpusat pada siswa maka terjadi proses pengembangan pada pribadi siswa. Baik pengembangan kognitif, afektif, dan psikomotor.

Mc Keachie dalam Dimyati (2002: 119) mengemukakan tujuh pilar keaktifan siswa yaitu (1) partisipasi siswa; (2) tekanan aspek afektif; (3) terjadi interaksi antarsiswa; (4) kekompakan kelas; (5) kebebasan belajar; (6) kesempatan berbuat dan mengambil keputusan; dan (7) pemberian waktu untuk menanggulangi masalah. Tujuh aspek tersebut saat proses siklus I dan II telah mampu memberikan kontribusi positif. Hal tersebut selaras dengan tujuh pilar CTL (kontekstual) dan unjuk kerja (karya) yang dilaksanakan selama siklus I dan II. Tujuh pilar CTL (kontekstual) meliputi konstruktivisme, inquiry, questioning, learning community, modeling, reflection, dan authentic assessment telah dilaksanakan selama siklus I dan II.

\section{SIMPULAN DAN SARAN}

Berdasarkan hasil penelitian yang telah dikemukakan di muka dapat dipaparkan kesimpulan sebagai berikut. 1) Penggunaan pendekatan kontekstual dapat meningkatkan apresiasi puisi bagi siswa kelas VII B semester 2 SMP Negeri 2 Mojosongo. Hasil tindakan diperoleh hasil bahwa dengan pendekatan kontekstual, hasil belajar yaitu dari kemampuan 
siswa mengapresiasi puisi saat kondisi awal semula rendah berubah menjadi kemampuan siswa mengapresiasi puisi saat akhir siklus II menjadi tinggi. 2) Penggunaan metode unjuk karya siswa dapat meningkatkan apresiasi puisi bagi siswa kelas VII B semester 2 SMP Negeri 2 Mojosongo. Hasil tindakan diperoleh hasil bahwa dengan unjuk karya hasil belajar yaitu dari kondisi awal apresiasi puisi semula rendah berubah menjadi kemampuan siswa mengapresiasi puisi menjadi tinggi. 3) Setelah guru melakukan tindakan dengan penggunaan pendekatan kontekstual dan metode unjuk karya rerata menulis kreatif puisi meningkat yaitu saat kondisi awal skor 69 meningkat saat akhir siklus II menjadi skor 78,74. Indikator kinerja untuk rerata skor 75 dapat terlampaui. Ketuntasan klasikal mengalami peningkatan saat kondisi awal adalah 3,1\% meningkat menjadi 96,87\% saat akhir siklus II. 4) Setelah guru melakukan tindakan dengan penggunaan pendekatan kontekstual dan metode unjuk karya rerata membaca puisi meningkat yaitu saat kondisi awal skor 69,43 meningkat saat akhir siklus II menjadi skor 78,53. Indikator kinerja untuk rerata skor 75 dapat terlampaui. Ketuntasan klasikal mengalami peningkatan saat kondisi awal semula $31,25 \%$ meningkat menjadi $100 \%$ saat akhir siklus II. Pemerolehan nilai hasil menanggapi cara pembacaan puisi juga mengalami peningkatan. Semula rerata 80,30 meningkat menjadi 81,87. 5) Setelah guru melakukan tindakan dengan penggunaan pendekatan kontekstual dan metode unjuk karya, keaktifan dan motivasi belajar siswa mengalami peningkatan.

Berdasarkan simpulan di atas, ada beberapa saran sebagai berikut. Pertama, siswa diharapkan rajin membaca buku-buku tentang sastra disertai latihan menulis dan membaca sehingga mampu mengapresiasi puisi secara maksimal. Kedua, guru hendaknya menggunakan pendekatan dan model pembelajaran yang bervariasi, memberikan augmented feedback, mengembangkan imajinasi dan kreativitas siswa, banyak memberikan contoh kepada siswa sehingga siswa akan termotivasi untuk belajar.

\section{DAFTAR PUSTAKA}

Aminudin. 2004. Pengantar Apresiasi Karya Sastra. Bandung: Sinar Baru.

Depdiknas. 2004. Kurikulum Berbasis Kompetensi. Jakarta.

Dimyati dan Mujiono. 2002. Belajar dan Pembelajaran. Jakarta: Rineka Cipta.

Direktorat Jenderal Pendidikan Dasar dan Menengah. 2004. Kurikulum 2004 Sekolah Menengah Pertama (SMP) Mata Pelajaran Bahasa dan Sastra Indonesia. Jakarta: Departemen Pendidikan Nasonal.

Herman J. Waluyo. 2002. Apresiasi Puisi untuk Pelajar dan Mahasiswa. Jakarta: PT Gramedia Pustaka Utama.

_ 2003. Apesiasi Puisi. Jakarta: Gramedia Pustaka Utama.

- 2008. Pengkajian dan Apresiasi Puisi. Salatiga: Widya Sari Press.

Kinayati Djojosuroto. 2005. Puisi dan Pembelajaran. Jakarta: Nuansa.

Kris Budiyono. 2009. Peningkatan Kemampuan Menulis Puisi Bebas dengan Media Lagu pada Siswa Kelas VIII D SMP N 9 Yogyakarta Tahun Pelajaran 2008/2009. (PTK yang tidak diterbitkan, Sertifikasi Jalur Pendidikan Mata Pelajaran Bahasa Indonesia Di UNY).

M. Faizal, dkk. 2009. Kajian Bahasa Indonesia SD. Jakarta: Dirjen Dikti Depdiknas.

Mulyadi HP. 2011. Penelitian Tindakan Kelas. Materi disajikan dalam Diklat Nasional KTI bagi peserta Forum Komunikasi Pengembangan Profesi Pendidik (FKP3) Kota Surakarta Bekerja Sama dengan Dinas 
Dikpora Kota Surakarta dan PGRI Kota Surakarta, Surakarta, April - Juli 2011.

Putu Arya Tirtawirya. 1982. Apresiasi Puisi dan Prosa. Flores: Nusa Indah.

Rachmad Djoko Pradopo. 2002. Pengkajian Puisi. Yogyakarta: Gajah Mada University Press.

S. Effendi. 1989. Bimbingan Apresiasi Puisi. Jakarta: Tangga Mustika Alam.

S. Parman Natawijaya. 1982. Apresiasi Satra dan Budaya. Jakarta: Intermasa.

Suminto A. Sayuti. 2002. Berkenalan dengan Puisi. Yogyakarta: Gama Media.

Sumiati dan Asra. 2007. Metode Pembelajaran. Bandung: Wacana Prima.

Sutrimah. 2009. Kemampuan Menulis Puisi Bebas Dengan Media Lagu Pada Siswa Kelas VIII D
SMPN 9 Yogyakarta Tahun Pelajaran 2008/2009. (PTK yang tidak diterbitkan, Sertifikasi Jalur Pendidikan Mata Pelajaran Bahasa Indonesia Di UNY).

Suyitno. 2004. Pembelajaran Apresiasi Puisi Sekolah Menengah Umum: Studi Kasus di SMU Negeri 1 dan SMU Negeri 8 Surakarta. (Penelitian Studi Kasus yang tidak diterbitkan, UNS).

Wardani. 1981. Pengajaran Sastra. Jakarta: Depdikbud.

Wina Sanjaya. 2008. Strategi Pembelajaran Berorientasi Standar Proses Pendidikan. Jakarta: Prenada Media Group.

Yamin, M. 2007. Kiat Membelajarkan Siswa. Jakarta: Gaung Persada Press. 